\title{
Probiotics with Antimicrobial Activity against Multidrug Resistant Pseudomonas aeruginosa and Acinetobacter baumannii
}

\author{
Do Kyung Lee ${ }^{1}$, Min Ji Kim ${ }^{1}$, Joo Yeon Kang ${ }^{2}$, Jae Eun Park ${ }^{2}$, Hea Soon Shin ${ }^{2}$, and Nam Joo Ha ${ }^{1 *}$ \\ ${ }^{1}$ College of Pharmacy, Sahmyook University, Seoul 139-742, Republic of Korea \\ ${ }^{2}$ College of Pharmacy, Duksung Women's University, Seoul 132-714, Republic of Korea
}

\section{다제내성 녹농균과 아시네토박터 바우마니에 항균활성을 가지는 프로바이오틱스}

\author{
이도경 ${ }^{1} \cdot$ 김민지 $^{1} \cdot$ 강주연 $^{2} \cdot$ 박재은 $^{2} \cdot$ 신혜순 $^{2} \cdot$ 하남주 $^{*}$ \\ ${ }^{1}$ 삼육대학교 약학대학, ${ }^{2}$ 덕성여자대학교 약학대학
}

(Received July 26, 2013 / Accepted August 16, 2013)

\begin{abstract}
Pseudomonas aeruginosa and Acinetobacter baumannii are significant opportunistic pathogens in hospitals and are resistant to most antibiotics. Multidrug-resistant $P$. aeruginosa (MDRPA) and $A$. baumannii (MDRAB) cause severe human nosocomial infections and are more difficult to treat than methicillin-resistant Staphylococcus aureus (MRSA). Bifidobacteria are among of the most beneficial probiotics and have been widely studied for their antimicrobial activities. The present study explored the antimicrobial activity of Bifidobacterium sp. isolated from healthy Koreans against MDRPA and MDRAB. The antimicrobial activity of the isolates against MDRPA and MDRAB, which are resistant to ciprofloxacin, tobramycin, gentamicin, meropenem, and ceftazidime, was determined by modified broth microdilution methods using absorbance. Among all tested bifidobacteria isolates (nine B. adolescentis, three B. longum, and two B. pseudocatenulatum), the culture supematant of B. pseudocatenulatum SPM1309 showed a strong growth inhibitory effect against MDRPA and MDRAB. No change in the turbidity of the mixture was observed during incubation, and its inhibitory effect occurred through bacteriostastic action. Moreover, the antibacterial activity was observed in the fraction with molecular weights $<10 \mathrm{kDa}$ of bifidobacteria culture supematant, and the active fraction was heat-stable because it maintained its activity when heated at $70{ }^{\circ} \mathrm{C}$ for 10 min. The results suggest that this Bifidobacterium strain could have potential applications for altemative therapy in MDRPA and MDRAB infections.
\end{abstract}

Keywords: Bifidobacterium, antimicrobial activity, multidrug-resistant Acinetobacter baumannii, multidrug-resistant Pseudomonas aeruginosa

Pseudomonas aeruginosa and Acinetobacter baumannii have emerged as important nosocomial pathogens that exhibit intrinsic resistance to a large range of antibiotics and remarkable ability to develop novel mechanisms of resistance during treatment (Navon-Venezia et al., 2005; Falagas and Kopterides, 2006). The infections caused by these bacteria are difficult to be treated with antibiotics and are associated with a higher rate of mortality because few or no adequate therapeutic option exists (Kuo et al., 2004; Deplano et al., 2005; Falagas et al., 2005; Shah, 2005). According to National Nosocomial Infections

*For correspondence. E-mail: hanj@syu.ac.kr; Tel.: +82-2-3399-1607; Fax: +82-2-3399-1617
Surveillance (NNIS), the prevalence of resistance in both pathogens is a significantly increasing trend (Gaynes and Edwards, 2005). Thus, novel strategies to control these strains are urgently needed.

Over the past decades, studies on beneficial health effects of probiotics or the substances they naturally produce have been actively progressing in various fields. Probiotics is defined as "good microorganisms that, administered in adequate amounts, confer health benefits on humans and that have been industrially prepared for nutritional and pharmaceutical use (Gill and Guarner, 2004; Parvez et al., 2006). Probiotics produce antimicrobial factors and compete with pathogens for essential nutrients, preventing excessive pathogen growth without causing 
bacterial resistance (Marteau and Shanahan, 2003). For an adequate amount of health benefits, a dose of 5 billion colony forming units (CFU) for at least 5 days $\left(5 \times 10^{9} \mathrm{CFU} /\right.$ day $)$ has been recommended (Gupta and Garg, 2009). The consumption of these products is growing rapidly all over the world and probiotics are generally recognized as safe (GRAS) (Gupta and Garg, 2009). Bifidobacteria as probiotics are a major beneficial bacterial group in the healthy human gut microbiota, and have multiple health effects, including (i) improving gastrointestinal (GI) tract health; (ii) synthesizing and enhancing the bioavailability of nutrients; (iii) modulating the immune system; (iv) lowering serum cholesterol; (v) blocking and eliminating pathogens; and (vi) reducing the risk of certain cancers (Guarner and Malagelada, 2003; Iannitti and Palmieri, 2010). Numerous studies showed that bifidobacteria have antimicrobial activity against several pathogenic microbial groups. There is also increasing interest in the research of antimicrobial peptides such as bacteriocins and bacteriocin-like compounds produced by bifidobacteria (Yildirim et al., 1999; De Vuyst et al., 2004; Servin, 2004; Makras and De Vuyst, 2006; Cheikhyoussef et al., 2008; Kondepudi et al., 2012; Rodriguez et al., 2012). However, only a very small number of antimicrobial compounds produced by bifidobacteria have been purified and characterized, despite their apparent benefits to human health. Thus, there is good potential in further research in this field (Cheikhyoussef et al., 2008).

The aim of this study was to examine the antimicrobial effects of sonicated cell extract and culture supernatant of Bifidobacterium sp. isolated from human intestinal microflora against multidrug resistant $P$. aeruginosa (MDRPA) and $A$. baumannii (MDRAB) and to explore the characteristics of its antimicrobial compound(s).

\section{Materials and Methods}

\section{Preparation of Bifidobacteria samples}

For the isolation of bifidobacteria, fecal samples were collected from twenty healthy Koreans (20-30 years old). Fecal samples were diluted and seeded onto selective blood liver agar (Nissui Pharm, Japan) containing 5\% sheep blood. After $48 \mathrm{~h}$ incubation in anaerobic conditions $\left(90 \% \mathrm{~N}_{2}, 5 \% \mathrm{H}_{2}, 5 \% \mathrm{CO}_{2}\right)$ using Bactron Anaerobic Chamber (Sheldon Manufacturing Inc., USA) at $37^{\circ} \mathrm{C}$, brown or reddish-brown colonies $2-3 \mathrm{~mm}$ in diameter were selected for further identification. A fructose-6-phosphate phosphoketolase (F6PPK) test was performed to ensure that the colonies selected were bifidobacteria (Ahn, 2005). It has been demonstrated that F6PPK activity serves as a taxonomic tool in the identification of the genus Bifidobacterium (Chevalier et al., 1990). To identify the isolated Bifidobacterium sp. at the species level, 16S rRNA sequencing was performed by Bio
Table 1. List of Bifidobacterium sp. isolates used in this study

\begin{tabular}{ccc}
\hline \multirow{2}{*}{ Species } & \multicolumn{2}{c}{ Origin } \\
\cline { 2 - 3 } & Sex & Age \\
\hline Bifidobacterium adolescentis & & \\
SPM0212 & Female & 21 \\
SPM0214 & Female & 21 \\
SPM0308 & Female & 22 \\
SPM1005 & Male & 25 \\
SPM1601 & Male & 20 \\
SPM1604 & Male & 20 \\
SPM1605 & Male & 20 \\
SPM1606 & Male & 20 \\
SPM1608 & Male & 20 \\
SPM1205 & & \\
SPM1206 & Female & 22 \\
SPM1207 & Female & 22 \\
SPM1204 & Female & 22 \\
SPM1309 & & \\
Bifidobacterium pseudocatenulatum & Female & 22 \\
& Male & 24 \\
\hline
\end{tabular}

leaders (Daejeon, Korea). According to the 16S rRNA sequencing, the isolates contained nine strains of $B$. adolescentis, three strains of B. longum, and two strains of B. pseudocatenulatum ( Table 1). Bifidobacterium sp. isolates were cultured at $37^{\circ} \mathrm{C}$ for $48 \mathrm{~h}$ in general anaerobic medium (GAM) broth (Nissui Pharm. Co. Ltd., Japan) under anaerobic conditions. For the preparation of bifidobacteria cell extracts, cells were harvested during the exponential growth phase by centrifugation at 4,000 rpm for 10 min, washed with PBS, and resuspended in the same buffer. These bacterial suspensions were then adjusted to a final concentration of $1.0 \times 10^{9} \mathrm{CFU} / \mathrm{ml}$ and sonicated for $6 \mathrm{~min}$ (amplitude 100\%). Cell extracts and culture supernatants were used after filtration $(0.2 \mu \mathrm{m})$.

Written informed consents were obtained from all volunteers who provided samples and the protocol was approved by the Institution Review Board of Office of Research Development, Sahmyook University.

\section{Clinical isolates}

$P$. aeruginosa and $A$. baumannii isolated from various clinical specimens, i.e., sputum, urine, wound, blood, stool, bronchial wash fluid, and incubation tube were provided by Sahmyook Medical Center. The isolates were stored at $-70^{\circ} \mathrm{C}$ in Nutrient broth (Difco, USA) with $20 \%$ glycerol before testing.

To select MDRPA and MDRAB, minimum inhibitory concentration (MIC) of six antibiotics [(ciprofloxacin (Ildong, Korea), tobramycin (Daewoong, Korea), tigecycline (Wyeth-Ayerst, USA), gentamicin (Sigma, USA), meropenem (Yuhan, Korea), and ceftazidime (GlaxoSmithKline, UK)] against clinical isolates were measured by the agar dilution method according to the guidelines established by the Clinical Laboratory and Standards Institute (CLSI, 2012). 


\section{Assay for growth inhibition by probiotics}

The antimicrobial activity of Bifidobacterium isolates against MDRPA and MDRAB was determined by modified broth microdilution methods using absorbance. MDRPA and MDRAB were cultured in Mueller-Hinton broth containing 25\% (v/v) cell extract or culture supernatant of bifidobacteria prepared as described above for $24 \mathrm{~h}$ at $37^{\circ} \mathrm{C}$. Growth inhibition was then detected by measuring absorbance of the mixtures at $625 \mathrm{~nm}$ using an ELISA reader (Molecular Devices, USA). As a control, MDRPA and MDRAB were cultured in Mueller-Hinton broth with the same amount of PBS or GAM broth.

\section{Characterization of antimicrobial compound(s)}

To examine the characteristics of antimicrobial compound(s), we heated the bifidobacteria sample for $10 \mathrm{~min}$ at $70^{\circ} \mathrm{C}$ or separated it by a molecular weight of $10 \mathrm{kDa}$ by using Amicon ${ }^{\circledR}$ Ultra- 0.5 Centrifugal Filter Devices (Millipore, USA). We then investigated the effect of heated or separated samples on growth inhibition as described above.

\section{Statistical analysis}

Results were expressed as mean \pm standard deviation (SD). Significant differences were separated using Duncan's multiple range test and commercial statistical analysis software, version 9.0 (SAS Institute, USA). All data were considered significant at $P<0.05$.

\section{Results}

The MICs of six antibiotics (ciprofloxacin, tobramycin, tigecycline, gentamicin, meropenem, and ceftazidime) against MDRPA and MDRAB are shown in Table 2. Most of the MDRPA exhibited high-level resistance to almost all antibiotics tested (MIC $128 \mu \mathrm{g} / \mathrm{ml}$ ). MDRAB was likewise highly resistant to some antibiotics. Also, all MDRAB exhibited resistance to meropenem and even tigecycline (Table 2).

Among all tested bifidobacteria isolates (nine B. adolescentis, three $B$. longum, and two B. pseudocatenulatum), the culture supernatant of B. pseudocatenulatum SPM1309 showed 90\% and $\sim 80 \%$ stronger growth-inhibitory effect against MDRPA and MDRAB, respectively. However, the cell extract of this strain did not show such inhibition. Also, B. pseudocatenulatum SPM1309 had an inhibitory effect but same species (SPM1204) did not have such inhibitory effect on MDRPA and MDRAB. Therefore its effect was not a species-specific but a strain-specific (Figs. 1 and 2).

The turbidity of the bacterial mixture did not change during incubation for $24 \mathrm{~h}$ (Fig. 3). However, a colony formed when this unchanged mixture was seeded onto new agar medium, and
Table 2. Minimum inhibitory concentration (MIC) of test antibiotics against multidrug-resistant $P$. aeruginosa and $A$. baumanii from clinical isolates

\begin{tabular}{ccccccc}
\hline \multirow{2}{*}{ Strains } & \multicolumn{7}{c}{ MIC $(\mu \mathrm{g} / \mathrm{ml})$} \\
\cline { 2 - 7 } & CIP & TOB & TIG & GEN & MEM & CAZ \\
\hline \multicolumn{2}{l}{ Pseudomonas aeruginosa } & & & & \\
CPA-1 & $>64$ & $>128$ & 128 & $>128$ & $>128$ & 128 \\
CPA-2 & 32 & $>128$ & 128 & $>128$ & $>128$ & 128 \\
CPA-3 & 64 & $>128$ & 128 & $>128$ & 128 & 32 \\
CPA-4 & 64 & $>128$ & 64 & 64 & $>128$ & 128 \\
Acinetobacter baumannii & & & & \\
CAB-1 & $>128$ & $>128$ & 8 & $>128$ & 16 & 64 \\
CAB-2 & 64 & $>128$ & 4 & $>128$ & 16 & $>128$ \\
CAB-3 & $>128$ & 32 & 4 & 32 & 16 & 128 \\
CAB-4 & $>128$ & $>128$ & 4 & $>128$ & 16 & $>128$ \\
\hline
\end{tabular}

CIP, ciprofloxacin; TOB, tobramycin; TIG, tigecycline; GEN, gentamicin; MEM, meropenem; CAZ, ceftazidime

its turbidity increased after incubation for $48 \mathrm{~h}$ (Fig. 3). Thus, this antibacterial activity of B. pseudocatenulatum SPM1309 was bacteriostastic in action. Moreover, the antibacterial activity was observed in the fraction with molecular weights $<10 \mathrm{kDa}$ of bifidobacteria culture supernatant, and active fraction was heat-stable because it maintained its activity when heated at $70^{\circ} \mathrm{C}$ for $10 \mathrm{~min}$ (Fig. 4 ).

\section{Discussion}

$P$. aeruginosa can produce disease in any part of the gastrointestinal (GI) tract from oropharynx to the rectum. The organism has been implicated in perirectal infections, pediatric diarrhea, typical gastroenteritis, and necrotizing enterocolitis. Chronic colonization of the GI mucosa is acknowledged to be an important component of $P$. aeruginosa diarrheal disease and systemic infections. The GI tract is an important portal of entry in Pseudomonas septicemia (Hentges et al., 1985; Marshall et al., 1993; Ohara and Itoh, 2003). Acinetobacter occasionally colonizes the gastrointestinal tract and is associated with bacteremia, and wound infections (Trottier et al., 2007).

Meropenem is a beta-lactam and belongs to the carbapenem subgroup, which is the first-line treatment of Acinetobacter infections (Bassetti et al., 2008). In the present study, all MDRAB isolates were resistant to meropenem and even tigecycline, which is a novel, broad-spectrum antibiotic that is active against MDRAB (Bassetti et al., 2008). In addition, most of the MDRPA isolates exhibited high-level resistance. However, the growth of both MDRAB and MDRPA isolates were inhibited by culture supernatant of $B$. pseudocatenulatum SPM1309. Some studies showed that bifidobacteria have antimicrobial activity against Pseudomonas species. According to Matsumoto et al. (2007) administration of B. longum significantly decreased viable counts of $P$. aeruginosa in the 

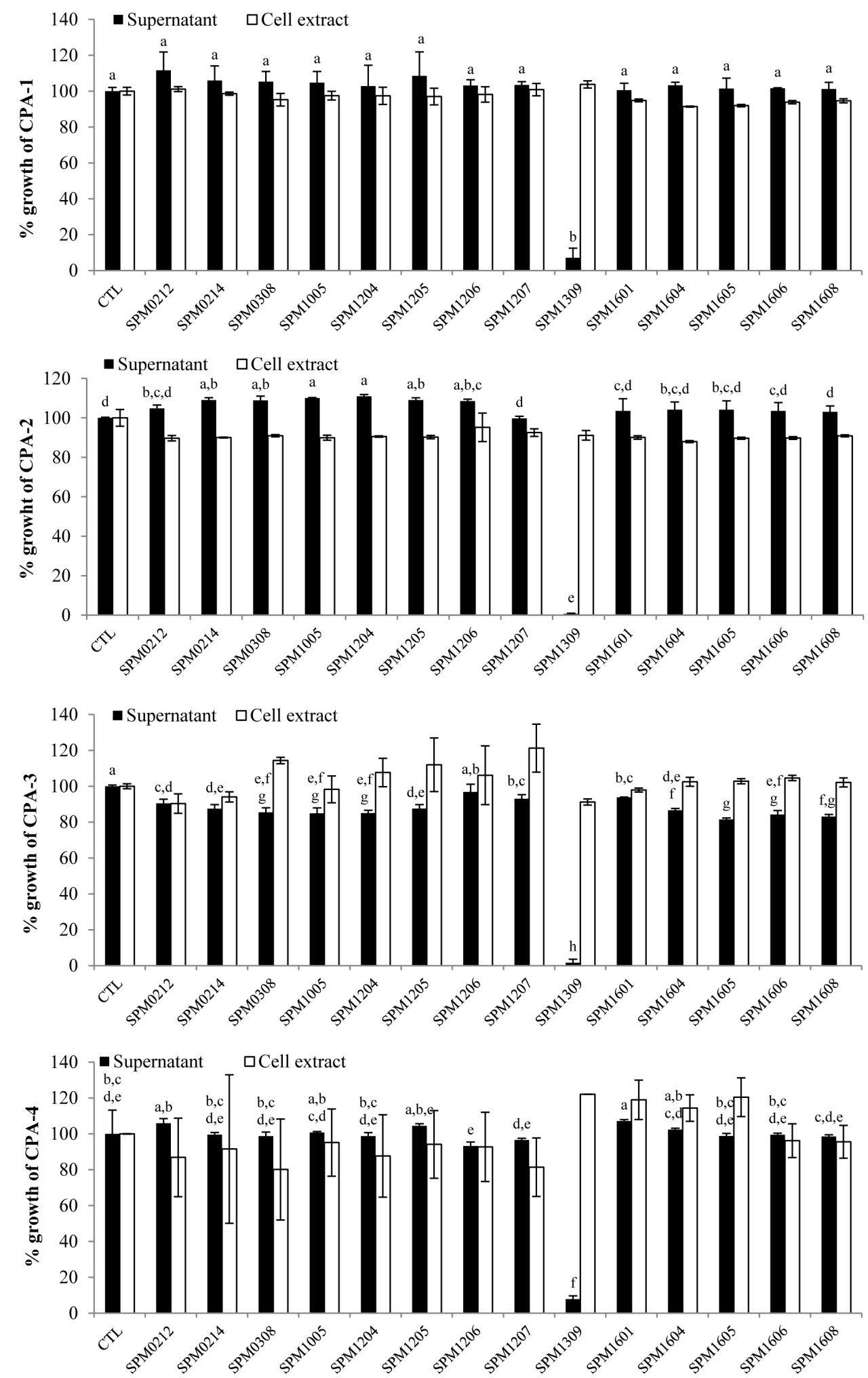

Fig. 1. Growth inhibitory effect of culture supernatants and cell extracts of bifidobacteria against multidrug-resistant $P$. aeruginosa. MDRPA were cultured in Mueller-Hinton broth containing $25 \%(\mathrm{v} / \mathrm{v})$ culture supernatant or cell extract of bifidobacteria for $24 \mathrm{~h}$ at $37^{\circ} \mathrm{C}$. Growth inhibition was determined by measuring absorbance at $625 \mathrm{~nm}$. As a control (CTL), MDRPA were cultured in Mueller-Hinton broth with the same amount of PBS or GAM broth. Data are presented as the growth rate of MDRPA. ${ }^{\mathrm{a} h}$ Means with no common superscripts differ significantly $(P<0.05)$. 

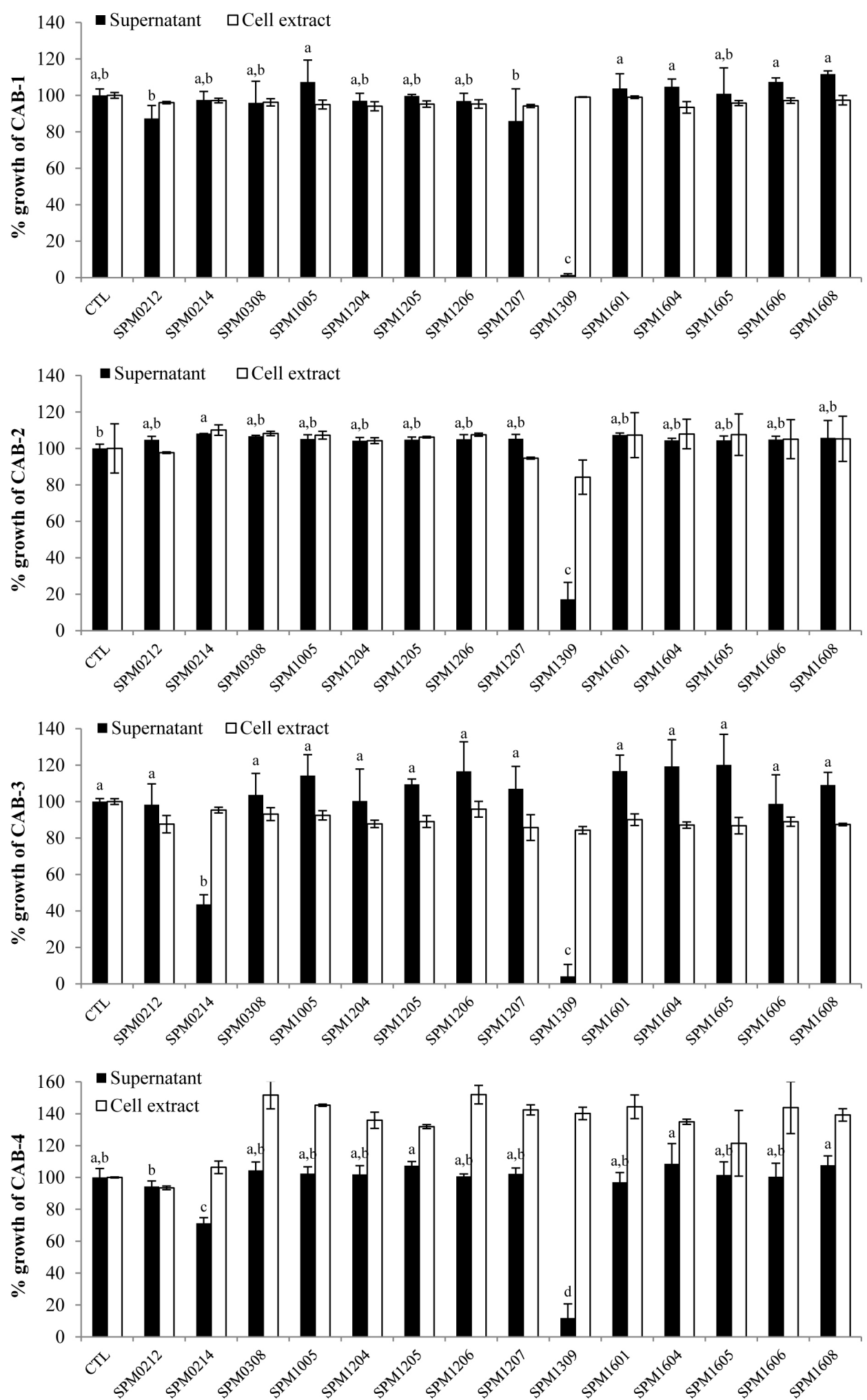

Fig. 2. Growth inhibitory effect of culture supernatants and cell extracts of bifidobacteria against multidrug-resistant $A$. baumannii. MDRAB were cultured in Mueller-Hinton broth containing $25 \%(\mathrm{v} / \mathrm{v})$ culture supernatant or cell extract of bifidobacteria for $24 \mathrm{~h}$ at $37^{\circ} \mathrm{C}$. Growth inhibition was determined by measuring absorbance at $625 \mathrm{~nm}$. As a control (CTL), MDRAB were cultured in Mueller-Hinton broth with the same amount of PBS or GAM broth. Data are presented as the growth rate of MDRPA. ${ }^{a-d}$ Means with no common superscripts differ significantly $(P<0.05)$. 
liver and blood. And culture of intestinal contents revealed a significantly lower viable count of $P$. aeruginosa in the jejunum of B. longum-treated mice. O'Riordan and Fitzgerald (1998) also reported that twelve strains of bifidobacteria exhibited a broad spectrum of antagonistic activity against both Gram-positive and Gram-negative indicators, especially Pseudomonas species. However, there are no studies that evaluate the effects of bifidobacteria against Acinetobacter species.

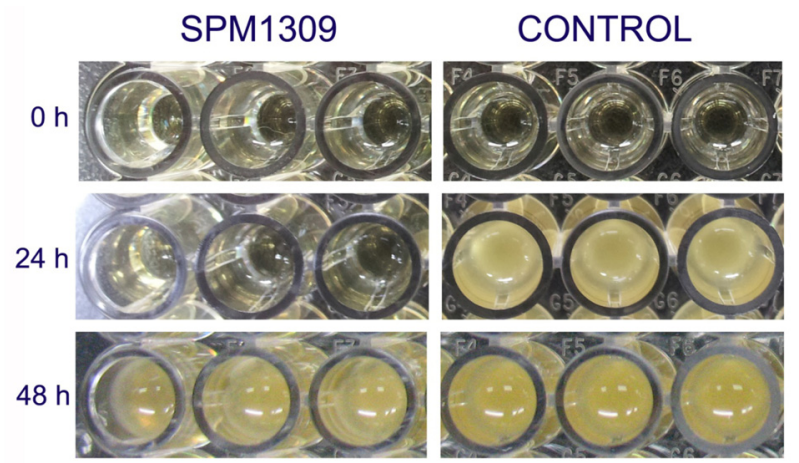

Fig. 3. The hourly change of turbidity in growth inhibitory effect of culture supernatant of B. pseudocatenulatum SPM1309.
Antibacterial activity of B. pseudocatenulatum SPM1309 was bacteriostastic in action. However, the antibacterial mechanism of B. pseudocatenulatum SPM1309 was not clearly elucidated. Several mechanisms have been suggested for the inhibitory action of bifidobacteria toward both gram-positive and negative pathogens, including a decrease of the local $\mathrm{pH}$ via the production of organic acids, the inhibitory action of undissociated organic acid molecules, competition for nutrients, competition for adhesion sites, stimulation of the host's immunity, and production of specific antibacterial substances (Fuller, 1989; Ballongue, 1998; De Vuyst et al., 2004). We may thus speculate that $B$. pseudocatenulatum inhibited the growth of MDRPA and MDRAB by the production of specific antimicrobial compound(s).

Numerous studies report on the inhibition of a wide range of pathogenic microorganisms, by bifidobacteria, both in vitro and in vivo (Yildirim et al., 1999; De Vuyst et al., 2004; Servin, 2004; Makras and De Vuyst, 2006; Cheikhyoussef et al., 2008; Kondepudi et al., 2012; Rodriguez et al., 2012). Antimicrobial activity of bifidobacteria was first noted by Tissier (1900), who described various types of antagonistic effects of B. bifidum against Escherichia coli (Tissier, 1990). Several bifidobacteria have the ability to produce antimicrobial compounds including
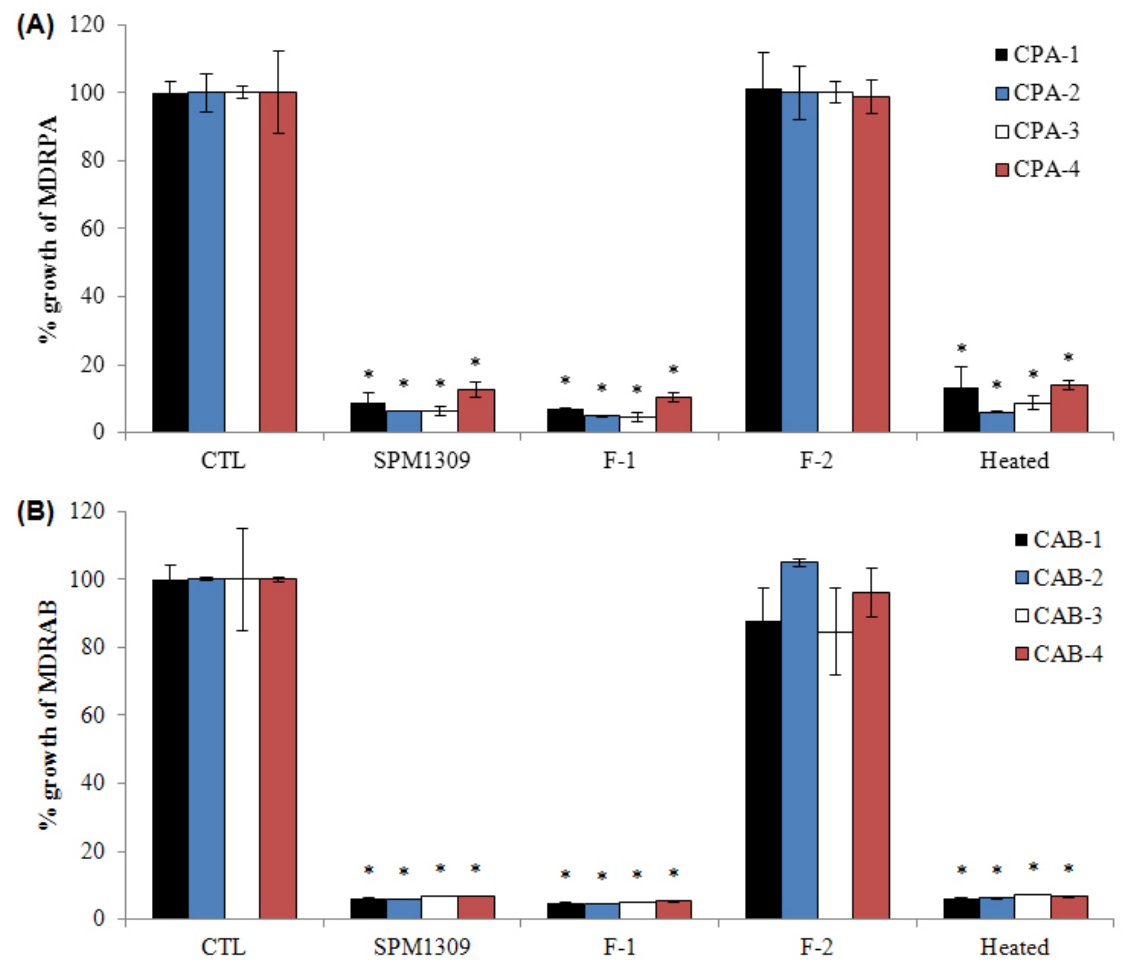

Fig. 4. Characterization of antibacterial compound(s) from culture supernatant of B. pseudocatenulatum SPM1309. MDRPA (A), and MDRAB (B) were cultured in Mueller-Hinton broth containing $25 \%(\mathrm{v} / \mathrm{v})$ B. pseudocatenulatum SPM1309 sample for $24 \mathrm{~h}$ at $37^{\circ} \mathrm{C}$. Growth inhibition was determined by measuring absorbance at $625 \mathrm{~nm}$. SPM1309, no treated culture supernatant of B. pseudocatenulatum SPM1309; F-1, the fraction with molecular masses lower than $10 \mathrm{kDa}$; F-2, the fraction with molecular masses higher than $10 \mathrm{kDa}$; Heated, heat treated culture supernatant of B. pseudocatenulatum SPM1309. ${ }^{*} P<0.05$. 
proteinaceous compounds called bacteriocins (Gibson and Wang, 1994; Yildirim and Johnson, 1998; Yildirim et al., 1999; Ibrahim and Salameh, 2001). Among the bacteriocins, Bifidin has been isolated from $B$. bifidum by a methanol-acetone extraction process and partial purification was achieved using Sephadex G-15 chromatography. Its inhibitory activity was observed after $30 \mathrm{~h}$ and the inhibition was maximal after $48 \mathrm{~h}$. Its optimum $\mathrm{pH}$ was 4.8 and maximum inhibition occurred in the $\mathrm{pH}$ range of 4.8 to 5.5. Bifidin is heat stable as it showed no loss in activity when heated at $100^{\circ} \mathrm{C}$ for $30 \mathrm{~min}$. This extract could be stored between 5 and $8^{\circ} \mathrm{C}$ for more than 3 months without any loss of its antimicrobial activity. The purified fraction of bifidin was reported to contain two amino acids in considerable amounts namely, phenylalanine and glutamic acid, but only trace amounts of amino acids like aspartic acid, threonine, serine, proline, glycine, isoleucine, and leucine (Anand et al., 1985). In the present study, the antibacterial activity of B. pseudocatenulatum SPM1309 was observed in the fraction with molecular weights under $10 \mathrm{kDa}$, and this active fraction showed no loss of activity when heated at $70^{\circ} \mathrm{C}$ for $10 \mathrm{~min}$.

Bifidobacteria are used worldwide in various traditional and industrial food fermentations (Hammes and Tichaczek, 1994). Bifidobacteria dominate the indigenous microbiota of infants, but their numbers decrease in adults (Gomes and Malcata, 1999; Guarner and Malagelada, 2003). Therefore, it is important to consistently consume the beneficial bifidobacteria.

In conclusion, B. pseudocatenulatum SPM1309 had a strong growth-inhibitory effect against both MDRPA and MDRAB. The molecular masses of the antimicrobial compound(s) from B. pseudocatenulatum SPM1309 were less than $10 \mathrm{kDa}$. In addition, it had bacteriostastic action and maintained its activity when heated at $70^{\circ} \mathrm{C}$ for $10 \mathrm{~min}$. The results suggest that $B$. pseudocatenulatum SPM1309 could be a useful probiotic microorganism for the prevention or alternative therapy of MDRPA and MDRAB infections. However, further identification of the active compound(s) and more information regarding this effect in various clinical conditions are needed.

\section{적 요}

녹농균과 아시네토박터 바우마니는 병원에서 중요한 기회감 염 균주이며 대부분의 항생제에 내성이다. 다제내성 녹농균 (MDRPA)과 아시네토박터 바우마니(MDRAB)는 심각한 원내 감염을 일으키고 메티실린 내성 황색포도상구균(MRSA) 보다 치료가 어렵다. 비피도박테리아는 많은 유익한 프로바이틱스 중 하나로 그들의 항균활성에 대한 많은 연구가 이루어져 왔다. 본 연구에서는 한국인으로부터 분리한 비피도박테리움 속 균주들 의 MDRPA와 MDRAB에 대한 항균활성을 조사하였다. 시프로
플록사신, 토브라마이신, 겐타마이신, 메로페넴과 세프타지딤에 내성을 보이는 MDRPA와 MDRAB에 대한 비피도박테리움 속 균주들의 항균활성은 흡광도를 이용한 액체배지희석법에 의해 측정되었다. 모든 비피도박테리아 분리균주(비피도박테리움 어 돌레센티스 9균주, 비피도박테리움 롱검 3균주와 비피도박테리 움 슈도카테눌라툼 2균주) 중 비피도박테리움 슈도카테눌라툼 $\mathrm{SPM} 1309$ 의 배양 상등액은 MDRPA와 MDRAB에 대한 강한 증식 억제 효과를 보여주었다. 배양 시간 동안 혼합액의 탁도는 변화되지 않았으며, 이 억제 효과는 정균 작용이었다. 게다가 항 균활성은 분자량 $10 \mathrm{kDa}$ 미만의 분획물에서 나타났으며, $70^{\circ} \mathrm{C}$ 에서 10 분간 열처리 한 후에서 항균활성이 유지되었기 때문에 활성물질은 열에 안정하였다. 본 연구결과는 MDRPA와 MDRAB 감염증의 대체치료법을 위한 비피도박테리움 슈토카테눌라툼 SPM1309의 잠재적인 가능성을 보여준다.

\section{Acknowledgements}

The authors are grateful to Sahmyook University, for the financial support. This work was supported by Business for Cooperative R\&D between Industry, Academy, and Research Institute funded Korea Small and Medium Business Administration (Grants No. 000449270111).

\section{References}

Ahn, J.B. 2005. Isolation and characterization of Bifidobacterium producing exopolysaccharide. Food Eng. Prog. 9, 291-296.

Anand, S.K., Srinivasan, R.A., and Rao, L.K. 1985. Antimicrobial activity associated with Bifidobacterium bifidum-II. Cult. Dairy Products J. 20, 21-23.

Ballongue, J. 1998. Bifidobacteria and probiotic action. pp. 519-587. In Salminen, S. and Von Wright, A. (eds.), Lactic Acid Bacteria: Microbiology and Functional Aspects. Marcel Dekker, New York, USA.

Bassetti, M., Righi, E., Esposito, S., Petrosillo, N., and Nicolini, L. 2008. Drug treatment for multidrug-resistant Acinetobacter baumannii infections. Future Microbiol. 3, 649-660.

Cheikhyoussef, A., Pogori, N., Chen, W., and Zhang, H. 2008. Antimicrobial proteinaceous compounds obtained from bifidobacteria: From production to their application. Int. J. Food Microbiol. 125, 215-222.

Chevalier, P., Roy, D., and Ward, D. 1990. Detection of Bifidobacterium species by enzymatic methods. J. Appl. Bacteriol. 68, 619-624.

Clinical and Laboratory Standards Institute (CLSI). 2012. Methods for dilution antimicrobial susceptibility tests for bacteria that grow aerobically; Approved standard, 9th ed. CLSI document M07-A79, CLSI, Wayne, PA, USA.

De Vuyst, L., Avonts, L., and Makras, L. 2004. Probiotics, prebiotics and gut health. pp. 416-482. In Remacle, C. and Reusens, B. (eds.), Functional Foods, Ageing and Degenerative Disease. Woodhead Publishing, Cambridge, UK.

Deplano, A., Denis, O., Poirel, L., Hocquet, D., nonhoff, C., Byl, B., Nordmann, P., Vincent, J.L., and Struelens, M.J. 2005. Molecular characterization of an epidemic clone of panantibiotic-resistant 
Pseudomonas aeruginosa. J. Clin. Microbiol. 43, 1198-1204.

Falagas, M.E., Bliziotis, I.A., Kasiakou, S., Samonis, G., Athanassopoulou, P., and Michalopoulos, A. 2005. Outcome of infections due to pandrug-resistant (PDR) Gram-negative bacteria. BMC Infect. Dis. 5, 24 doi:10.1186/1471-2334-5-24.

Falagas, M.E. and Kopterides, P. 2006. Risk factors for the isolation of multi-drug-resistant Acinetobacter baumannii and Pseudomonas aeruginosa: a systematic review of the literature. J. Hosp. Infect. 64, $7-15$.

Fuller, R. 1989. Probiotics in man and animals. J. Appl. Bacteriol. 66, 365-378

Gaynes, R. and Edwards, J.R. 2005. National nosocomial infections surveillance system. Overview of nosocomial infections caused by Gram-negative bacilli. Clin. Infect. Dis. 41, 848-854.

Gibson, G.R. and Wang, X. 1994. Regulatory effects of bifidobacteria on the growth of other colonic bacteria. J. Appl. Bacteriol. 77, 412 420.

Gill, H.S. and Guamer, F. 2004. Probiotics and human health: a clinical perspective. Postgrad. Med. J. 80, 516-526.

Gomes, A.M.P. and Malcata, F.X. 1999. Bifidobacterium spp. and Lactobacillus acidophilus: Biological, biochemical, technological and therapeutical properties relevant for use as probiotics. Trends Food Sci. Technol. 10, 139-157.

Guamer, F. and Malagelada, J.R. 2003. Gut flora in health and disease. Lancet 361, 512-519.

Gupta, V. and Garg, R. 2009. Probiotics. Indian J. Med. Microbiol. 27, 202-209.

Hammes, W.P. and Tichaczek, P.S. 1994. The potential of lactic acid bacteria for the production of safe and wholesome food. Z. Lebensm. Unters. Forsch. 198, 193-201.

Hentges, D.J., Stein, A.J., Casey, S.W., and Que, J.U. 1985. Protective role of intestinal flora against infection with Pseudomonas aeruginosa in mice: influence of antibiotics on colonization resistance. Infect. Immun. 47, 118-122.

Iannitti, T. and Palmieri, B. 2010. Therapeutical use of probiotic formulations in clinical practice. Clin. Nutr. 29, 701-725.

Ibrahim, S.A. and Salameh, M.M. 2001. Simple and rapid method for screening antimicrobial activities of Bifidobacterium species of human isolates. J. Rapid Methods Autom. Microbiol. 9, 52-63.

Kondepudi, K.K., Ambalam, P., Nilsson, I., Wadstrom, T., and Ljungh, A. 2012. Prebiotic-non-digestible oligosaccharides preference of probiotic bifidobacteria and antimicrobial activity against Clostridium difficile. Anaerobe 18, 489-497.

Kuo, L.C., Teng, L.J., Yu, C.J., Ho, S.W., and Hsueh, P.R. 2004. Dissemination of a clone of unusual phenotype of pandrug-resistant
Acinetobacter baumannii at a university hospital in Taiwan. J. Clin. Microbiol. 42, 1759-1763.

Makras, L. and De Vuyst, L. 2006. The in vitro inhibition of Gram-negative pathogenic bacteria by bifidobacteria is caused by the production of organic acids. Int. Dairy J. 16, 1049-1057.

Marshall, J.C., Christou, N.V., and Meakins, J.L. 1993. The gastrointestinal tract. The "undrained abscess" of multiple organ failure. Ann. Surg. 218, 111-119.

Marteau, P. and Shanahan, F. 2003. Basic aspects and pharmacology of probiotics: An overview of pharmacokinetics mechanisms of action and side-effects. Best Pract. Res. Clin. Gastroenterol. 17, 725-740.

Matsumoto, T., Ishikawa, H., Tateda, K., Yaeshima, T., Ishibashi, N., and Yamaguchi, K. 2007. Oral administration of Bifidobacterium longum prevents gut-derived Pseudomonas aeruginosa sepsis in mice. J. Appl. Microbiol. 104, 672-680.

Navon-Venezia, S., Ben-Ami, R., and Carmeli, Y. 2005. Update on Pseudomonas aeruginosa and Acinetobacter baumannii infections in the healthcare setting. Curr. Opin. Infect. Dis. 18, 306-313.

Ohara, T. and Itoh, K. 2003. Significance of Pseudomonas aeruginosa colonization of the gastrointestinal tract. Int. Med. 42, 1072-1076.

O'Riordan, K. and Fitzgerald, G.F. 1998. Evaluation of bifidobacteria for the production of antimicrobial compounds and assessment of performance in cottage cheese at refrigeration temperature. J. Appl. Microbiol. 85, 103-114.

Parvez, S., Malik, K.A., Ah Kang, S., and Kim, H.Y. 2006. Probiotics and their fermented food products are beneficial for health. J. Appl. Microbiol. 100, 1171-1185.

Rodriguez, E., Arques, J.L., Rodriguez, R., Peiroten, A., Landete, J.M., and Medina, M. 2012. Antimicrobial properties of probiotic strains isolated from breast-fed infants. J. Funct. Foods 4, 542-551.

Sevin, A.L. 2004. Antagonistic activities of lactobacilli and bifidobacteria against microbial pathogens. FEMS Microbiol. 28, 405-440.

Shah, P.M. 2005. The need for new therapeutic agents: what is the pipeline? Clin. Microbiol. Infect. 11, 36-42.

Tissier, H. 1990. Ph. D. Thesis, University of Paris, Paris, France.

Trottier, V., Segura, P.G., Namias, N., King, D., Pizano, L.R., and Schulman, C.I. 2007. Outcomes of Acinetobacter baumannii infection in critically I11 burned patients. J. Burn. Care Res. 28, 248-254.

Yildirim, Z. and Johnson, M.G. 1998. Characterization and antimicrobial spectrum of bifidocin B, a bacteriocin produced by Bifidobacterium bifidum NCFB 1454. J. Food Prot. 61, 47-51.

Yildirim, Z., Winters, D.K., and Johnson, M.G. 1999. Purification, amino acid sequence and mode of action of bifidocin B produced by Bifidobacterium bifidum NCFB 1454. J. Appl. Microbiol. 86, 45-54. 